\title{
Evaluation of Salmonella Species in Water Sources in Two Local Government Areas of Anambra State
}

\author{
Ekelozie Ifeoma Stella ${ }^{1 *}$, Ekejindu Ifeoma $\mathrm{M}^{1}$, Ochiabuto OMTB ${ }^{1}$, Obi MC $^{1}$, Onwuasonya UF ${ }^{1}$ and Obeagu \\ Emmanuel Ifeanyi ${ }^{2}$
}

${ }^{1}$ Department of Medical Laboratory Science, Nnamdi Azikiwe University, Nigeria

${ }^{2}$ Department of Health Services, Michael Okpara University of Agriculture, Nigeria

*Corresponding author: Ekelozie Ifeoma Stella, Department of Medical Laboratory Science, Nnamdi Azikiwe University, Nnewi Campus, Nnewi, Anambra State, Nigeria

Submission: 海 November 13, 2017; Published: 眥 January 04, 2018

\begin{abstract}
Microbial quality of water using Salmonella species in water sources was investigated in two Local Government Areas in Anambra State, between the months of September and December, 2013. A total of 220 water samples were analyzed using Bacteriological Analytic method and membrane filtration method. Antimicrobial Susceptibility test by disc diffusion method and serotyping was done using slide agglutination methods with polyvalent antiserum. Salmonella species was most prevalent (35.0\%) in Reservoir water samples and least prevalent (7.45) in Borehole-water samples examined. Salmonella typhi had the highest prevalence rate of (40.05), Salmonella enteric (92.80\%), Salmonella paratyphoid A (23.05), and Salmonella paratyphoid C least prevalent (9.43\%). Antibiotic susceptibility test showed that 24 Salmonella species (44.46\%) were sensitive to10ug Ciproflaxin while Penicillin $(30 \mathrm{mg})$ had the highest resistance rate of $54(100 \%)$. This study portrays the diversity of Salmonella species and indicator organisms in water sources in the study area. There is need therefore to put in place appropriate intervention strategies to control the spread of Salmonella bacilli from these sources to human population.
\end{abstract}

Keywords: Salmonella species; Water sources; Two Local government areas of anambra state

\section{Introduction}

Water is an essential part of human nutrition, both directly as drinking water or indirectly as constituent of food; in addition to various other applications in daily life. Water is not only essential for life, it also remains a most important vehicle of transmitting disease and infant mortality in many developing countries and even in technologically more advanced countries [1]. Good quality water is odorless, colourless, tasteless, and free from fecal pollution [2]. However, it is estimated that about 1.2billion individuals world-wide do not have access to potable water. In many developing countries, availability of water has become a critical and urgent problem and it is a matter of great concern to families and communities that depend on non-public water supply system [3]. Increase in human population has exerted an enormous pressure on the provision of safe drinking water in developing countries [4]. To curb this health problem, bottled water was introduced but only individuals who have a good financial status can afford these products. Low income earners are left with no option but to consume sachet water, borehole water, wells, reservoirs, surface waters that are usually not free of microbial contaminants [5]. The potential ability of drinking water to transmit microbial pathogens to great number of people causing subsequent illness is well document in many countries at all levels of economic development [6]. Water pollution has continued to create negative impacts on health and economic development in Nigeria [7]. High incidence of childhood diarrhoea, helminthiasis, trachoma, typhoid fever and the overall high mortality rates are associated with poor environmental sanitation [8]. Therefore, this study evaluates Salmonella from drinking water source to determine the portability of the water.

Salmonella is a genus of rod-shape, gram negative, non sporeforming, predominantly motile Enterobacteria with diameters around 0.7 to $1.5 \mu \mathrm{m}$, lengths from 2 to $5 \mu \mathrm{m}$ and flagella that move in all directions. They are chemo organotrophs, obtaining their energy from oxidation and reduction reactions using organic sources and are facultative anaerobes. Most species produce hydrogen sulfide [9] which can readily be detected by growing them on media containing ferrous sulfate. Most isolates exist in two phases: a motile phase (I) and a non motile phase (II). Cultures that are nonmotile upon primary culture may be switched to the motile phase. Salmonella is closely related to the Escherichia genus and are found worldwide in cold and warm blooded animals (including humans), and in typhoid fever, paratyphoid fever and food borne illness [10].

Salmonellosis is a food borne infection caused by a group of gramnegative motile rods belonging to the family of Enterobacteriaceae. The genus Samonella which causes Salmonellosis comprises several 
species of which Salmonella typhi and Salmonella paratyphi are the main species pathogenic to man. The species Salmonella typhimurium is the common cause of gastroenteritis, while Salmonella chloreraesus is responsible for septicemia. Salmonellosis is associated with several symptoms including diarrhoea, vomiting, nausea, abdominal pain and fever. Untreated cases could become chronic or fatal. The portal of entry for Salmonellosis is through ingestion of contaminated food and/or water contaminated with animal or human faeces. The infection is commonly treated with antibiotics such as Ampicillin, Chloramphenicol, Trimethoprim, Sulpha-methaxazole, and Cephalosporin. Salmonellosis can be controlled or prevented by adequate supervision of food and water, as well as improved personal hygiene [11]. As a result of the serious consequences and threats to health and economic development which water pollution poses, this work is therefore embarked upon to ascertain the microbial quality of drinking water with the following aim and objectives.

\section{Aim}

To evaluate the microbial water quality of various domestic water sources by the presence of Salmonella species.

\section{Specific Objectives}

i. To determine the bacteriological quality of ground water and surface water used for drinking in Nnokwa, Alor, Nnobi, Abatete and Oraukwu.

ii. To ascertain the prevalence of different salmonella species in different water sources.

iii. To isolate and identify the various salmonella serovas found in the water sources.

iv. To determine the susceptibility pattern of salmonella isolates from different water sources.

v. To compare the water quality between the areas and their sources.

\section{Materials and Method}

Study area: This work was carried out in some selected communities in Idemili North and South LGA.

Methods of sample collection: A total of 220 water samples were collected, 50 samples were collected each from these water sources (well, borehole, reservoirs and surface water) and 20 controls (sterile water) between the months of September and December 2013.

Storage and transport: The water samples were immediately stored in an ice box at low temperature and immediately transported to the laboratory. Samples were analyzed within 6 hours of collection [12].

Analysis of sample: Two methods namely;

a) Membrane filtration method [12]

b) And Dilution Method of standard analytical protocol [13] were used for sample analysis.

\section{Isolation of salmonella}

\section{Membrane filtration method}

a) Day 1 - Pre-enrichment (Non-selective enrichment): Water samples $(100 \mathrm{ml})$ were filtered through a sterile $(0.45 \mu \mathrm{m})$ milipore membrane filter. The membrane filter was lifted with a blunt edge forceps and transferred into $90 \mathrm{ml}$ of buffered peptone water. These were gently mixed and incubated for overnight at 37 0C.

b) Day 2 - Selective enrichment I \& II method: A $1 \mathrm{ml}$ volume of the pre-enrichment agar was transferred with a pipette into $10 \mathrm{ml}$ Tetrathionate broth and $0.1 \mathrm{ml}$ of the pre-enrichment was transferred with a pipette into $10 \mathrm{ml}$ Rappaport-Vassiliadis Soy Peptone (RVS) broth was incubated at 37 0C.

c) Day 3 - Selective plating method: A 10 $\mu$ l loopful of culture each from the tube 1 and tube 2 were streaked on selective agar Chromagar Salmonella (France) and Miller Mallinson agar (Switzerland) respectively and incubated at 37 0C overnight. Colonies of the suspected Salmonella species on chrom agar salmonella appeared as mauve colonies and grey black on miller malison agar. Presumptive Salmonella isolates were purified on MacConkey agar plates. Suspected colonies of salmonella were streaked onto MacConkey agar for purification and to achieve single colony. The plates were incubated at $370 \mathrm{C}$ for $24 \mathrm{hrs}$.

\section{Dilution method}

a) Pre-enrichment (non-selective enrichment) method: Tubes are arranged in three rows $(10 \mathrm{ml}$ of $3 \mathrm{x}, 5 \mathrm{ml}$ of $3 \mathrm{x}$ and $10 \mathrm{ml}$ of $1 \mathrm{x}$ ) of five tubes each. To the first row $-10 \mathrm{ml}$ of $3 \mathrm{x}$ universal preenrichment broth: $20 \mathrm{ml}$ of water sample was inoculated to each of the five tubes of $10 \mathrm{ml}$ of $3 x$ universal pre-enrichment broth. To the second row $-5 \mathrm{ml}$ of $3 \mathrm{x}$ universal pre-enrichment broth: $10 \mathrm{ml}$ of water sample was inoculated to each of the five tubes containing $5 \mathrm{ml}$ of $3 \mathrm{x}$ UPB. To the $3 \mathrm{rd}$ row $-10 \mathrm{ml}$ of $1 \mathrm{x}$ universal pre-enrichment broth: $1 \mathrm{ml}$ of water sample was inoculated into each of the five tubes of $10 \mathrm{ml}$ of $1 \mathrm{x}$ UPB. All the tubes were incubated at $37 \mathrm{OC}$ for $24 \pm 2 \mathrm{hrs}$.

b) Selective enrichment: From each tube with growth $1.0 \mathrm{ml}$ of the pre-enrichment broth Selenite Cystine broth was prepared according to manufacturer's instruction, was transferred into $10 \mathrm{ml}$ of selenite cystine broth. The tubes were shaken and incubated at 37 0C $24+2 \mathrm{hrs}$.

c) Selective plating: $3 \mathrm{ml}$ loopful $(10 \mu \mathrm{L})$ of the incubated medium was streaked on Chromagar Salmonella and MillerMallinson agar (MM agar).These were incubated at 37 OC for $24 \mathrm{hrs}$. Plates were examined for the presence of suspected colonies Salmonella. Suspected colonies were streaked onto tryptic soya agar for purification, biochemical and serological identification. The plates were incubated at $370 \mathrm{C}$ for $24 \mathrm{hrs}$.

\section{Biochemical test for identification of isolates}

\section{a) Triple sugar iron agar (TSIA)}

Procedure: A small amount of growth was harvested with a 
sterile inoculating needle, a single stab was made into the butt of the tube and the surface of the agar slant lightly inoculated. Tubes were incubated under aerobic conditions at 36+10C with the caps loosened. Tubes were examined for acid butt and alkaline slant, gas production and hydrogen sulphide production at $24 \mathrm{hrs}, 48 \mathrm{hrs}$ for 5-7 days (unless H2S production occurred sooner) [13].

\section{b) Lysine iron agar (LIA)}

Procedure: A small amount of growth was harvested with a sterile inoculating needle, a single stab was made into the butt of the tube and the surface of the agar slant was lightly inoculated. Tubes were incubated under aerobic conditions at 36+10C with cap loosened. Tubes were examined for Hydrogen sulphide production.

\section{c) Simmons citrate utilization test}

Procedure: A small amount of growth was harvested with a sterile inoculating loop. The surface of the agar slant was lightly inoculated. Tubes were incubated under aerobic conditions at $36+1$ 0C with caps loosened. Tubes were examined for change in colour from blue to green and result recorded at $24 \mathrm{hrs}$, $4 \mathrm{hrs}$ for 5-7 days.

\section{d) Motility -indole-urea (MIU)}

Procedure: A small amount of growth was harvested with a sterile needle. A single stab was made into the tube of MIU agar. The stab was made straight into the agar and stopped approximately Icm from the bottom of the tube. And Kovac's reagent paper attached at the neck of the test tube. Tubes were incubated under aerobic conditions at 36+1 0C with caps loosened. Tubes were examined for motility, indole production seen on Kovac's reagent paper and urease production and results recorded following over night (1824hrs) incubation [14].

\section{e) Sugar fermentation test}

Procedure: Bijou bottles containing about $6 \mathrm{ml}$ aliquot of peptone water medium, bromothymol blue indicator and inverted durham tube were sterilized at $1210 \mathrm{C}$ for 15 minutes in the autoclave. One percent of the sugar prepared by dissolving $1 \mathrm{~g}$ of the sugar in $10 \mathrm{ml}$ of water and sterilized by steaming for 30 minutes. The bottles were allowed to cool. Sugar solution of $0.3 \mathrm{ml}$ volumes each were aseptically dispensed into bijou bottles containing the basal medium and inoculated with $24 \mathrm{hrs}$ culture of each of the isolate and incubated at $370 \mathrm{C}$. The production of acid and gas were observed after $24 \mathrm{hrs}$. Acid production was indicated by change in colour of the medium from red to yellow while gas production was indicated by the presence of bubble in the durham tube.

\section{f) Oxidase test}

Procedure: Three drops of freshly prepared oxidase reagent were place on to a paper in a petri disc. With sterile platinum

\section{Results}

In Table 1, Salmonella typhi had the most occurrences both in wells, boreholes, reservoirs and surface water using B.A.M method. In Table 2, Salmonella typhi had the most occurrence both in wells, boreholes, reservoirs and surface water using Membrane Filtration wire loop, some of the growths were smear on the prepared filter paper. Appearance of deep blue purple colour within 10 seconds was regards as positive reaction. Salmonella is oxidase negative, pseudoman eroginosa oxidase positive.

\section{Antibiotic susceptibility test of salmonella isolates}

The sensitivity of the pure culture of bacterial isolates to different antibiotics was determined using the Kirby bauer diffusion technique and interpreted based on the guidelines of the clinical and laboratory standards [15]. Commercially prepared antimicrobial disc (Optum Diagnostic Nigeria) were used and it contained the following antibacterial agents. Ciprofloxacin (10mcg), Streptomycin (30ug), Preflacine (10ug), Septrin (30ug), Ampicilin (30ug), Tarivid (10ug), Penicillin (10 mcg), Gentamycin (10mcg), Augmentin (30mcg), Nalidic Acid (30mcg). Muller Hinton agar plates prepared according to manufacturer's instructions were used. Commercially prepared antimicrobial disc were placed in the Muller Hinton agar plates after seeding the media with suspected Salmonella isolates. These were incubated at $370 \mathrm{C}$ for $24 \mathrm{hrs}$ after which zones of clearance or inhibition were noted and recorded accordingly in $\mathrm{mm}$.

\section{Serological identification of Salmonella}

I. Widal kit (cromatestwidal) was used to support the tentative identification of isolates as member of salmonella specie. Widal test is a serological technique which test for the presence of Salmonella antibodies. It is a screening test used in diagnosing typhoid and paratyphoid fever [12].

\section{Serotyping of salmonella using polyvalent antiserum} method

Three separate drops of normal saline were placed on a clean glass slide using a wire loop. Growth from the overnight culture plate of tryptic Soy Agar was emulsified in each separate drop of normal Saline. A loop of Salmonella Polyvalent 'O' (PSO) anti-serum was then mixed with the first drop of suspension of normal saline while a loop ful of Salmonella Polyvalent 'H' antiserum was mixed with the second drop of normal saline. To the third drop (control), one loopful of normal Saline was added. All bacterial Suspension was mixed using a sterile wire loop. The slide was gently tilt back and front for one minute and observed for agglutination under normal light condition. Presence of agglutination indicates positive reaction.

\section{Statistical Analysis}

Statistical Analysis of results was done using Anova, T-test, Chisquare. Level of significant was set at 95\% confidence limit and 0.05 levels respectively. Statistical Package for Social Science (SPSS) Software Version 16 was used for evaluation.

Method. In Table 3 below, Salmonella typhi had the highest frequency of 5(38.5\%) while Salmonella paratyphi C has the least frequency of $1(7.7 \%)$. In Table (4-10) below, well water at Nnokwa had the highest Salmonella Spp. of $80(8.03 \%)$, Alor had the highest Salmonella Spp. in surface water, borehole and reservoir and Nnobi had no Salmonella Spp. in borehole water. 
Table 1: Different species of Salmonella isolated from various water samples using bacteriological analytical method (B.A.M).

\begin{tabular}{|c|c|c|c|c|c|}
\hline Microorganism (cfu/100ml) & Wells & Boreholes & Reserviors & Surface Water & Total \\
\hline Salmonella typhi & 4 & 2 & 5 & 5 & 16 \\
\hline Salmonella paratyphi A & 2 & 0 & 3 & 3 & 4 \\
\hline Salmonella paratyphi C & 1 & 0 & 0 & 5 & 13 \\
\hline Salmonella enterica & 3 & 2 & 3 & 11 & 41 \\
\hline Total & 10 & 4 & 11 & & \\
\hline
\end{tabular}

Table 2: Different species of Salmonella isolated from various water samples using membrane filtration method.

\begin{tabular}{|c|c|c|c|c|c|}
\hline Microorganism (Cfu/100ml) & Wells & Boreholes & Reserviors & Surface Water & Total \\
\hline Salmonella typhi & 2 & 0 & 3 & 0 & 5 \\
\hline Salmonella paratyphi A & 0 & 0 & 3 & 1 & 4 \\
\hline Salmonella paratyphi C & 0 & 0 & 0 & 0 & 3 \\
\hline Salmonella enterica & 1 & 0 & 2 & 2 & 13 \\
\hline Total & 3 & 0 & 8 & & \\
\hline
\end{tabular}

Table 3: Frequency of different Salmonella species isolated from various water samples using membrane filtration method.

\begin{tabular}{|c|c|c|}
\hline Microorganism (Cfu/100ml) & Frequency & \multicolumn{2}{|c|}{ Percentage (\%) } \\
\hline Salmonella typhi & 5 & 38.5 \\
\hline Salmonella paratyphi A & 4 & 7.8 \\
\hline Salmonella paratyphi C & 1 & 23.1 \\
\hline Salmonella enterica & 3 & 100 \\
\hline Total & 13 & \\
\hline
\end{tabular}

Table 4: Prevalence of total Salmonella spp. isolated from water bodies in Idemili North (Oraukwu and Abatete)

\begin{tabular}{|c|c|c|c|c|c|}
\hline Sources & $\begin{array}{l}\text { Salmonella typhi } \\
\text { (Cfu/100ml) }\end{array}$ & $\begin{array}{c}\text { Salmonella paratyphi } A \\
\text { (Cfu/100ml) }\end{array}$ & $\begin{array}{c}\text { Salmonella paratyphi } C \\
\text { (cfu/100ml) }\end{array}$ & $\begin{array}{l}\text { Salmonella enteric } \\
\text { (cfu/100ml) }\end{array}$ & Total \\
\hline \multicolumn{6}{|c|}{ Oraukwu } \\
\hline $\begin{array}{l}\text { Surface } \\
\text { water }\end{array}$ & $17(20.0)$ & $23(20.0)$ & $28(20.1)$ & $2(20.0)$ & $70(42.9)$ \\
\hline Borehole & $2(16.7)$ & 0 & $4(22.2)$ & $8(20.0)$ & $14(8.59)$ \\
\hline Reservior & $30(25.0)$ & $27(50.0)$ & 0 & 0 & $57(34.97)$ \\
\hline \multicolumn{6}{|c|}{ Abatete } \\
\hline Borehole & 0 & $2(20.0)$ & 0 & 0 & $2(1.23)$ \\
\hline Reservior & $20(25.0)$ & 0 & 0 & 0 & $20(12.3)$ \\
\hline
\end{tabular}

Table 5: Prevalence Salmonella spp isolated from water bodies in Idemili South (Nnobi, Nnokwa and Alor).

\begin{tabular}{|c|c|c|c|c|c|}
\hline Sources & $\begin{array}{l}\text { Salmonella typhi } \\
\text { (CFU/100ml) }\end{array}$ & $\begin{array}{c}\text { Salmonella } \\
\text { paratyphi A } \\
\text { (CFU/100ml) }\end{array}$ & $\begin{array}{c}\text { Salmonella paratyphi } C \\
\text { (CFU/100ml) }\end{array}$ & Salmonella enterica $(\mathrm{CFU} / 100 \mathrm{ml})$ & Total \\
\hline \multicolumn{6}{|c|}{ Nnobi } \\
\hline $\begin{array}{l}\text { Surface } \\
\text { water }\end{array}$ & 0 & 0 & $5(16.7)$ & $4(18.2)$ & $9(0.9)$ \\
\hline Reservior & $6(31.6)$ & 0 & 0 & $17(34.0)$ & $23(2.31)$ \\
\hline Borehole & 0 & 0 & 0 & 0 & 0 \\
\hline \multicolumn{6}{|c|}{ Alor } \\
\hline $\begin{array}{l}\text { Surface } \\
\text { water }\end{array}$ & $7(17.5)$ & $6(17.1)$ & $2(20.0)$ & $3(15.0)$ & 18(1.81) \\
\hline Borehole & $39(50.0)$ & $15(50.0)$ & 0 & 0 & $54(5.4)$ \\
\hline Reservior & $50(33.3)$ & $10(33.3)$ & 0 & 0 & $60(6.02)$ \\
\hline \multicolumn{6}{|c|}{ Nnokwa } \\
\hline Well & $34(16.9)$ & $5(16.1)$ & $8(16.0)$ & $33(16.5)$ & $80(8.03)$ \\
\hline
\end{tabular}


Table 6: Comparism of Salmonella spp found in surface water in Idemili South and Idemili north LGA of anambra state.

\begin{tabular}{|c|c|c|c|c|}
\hline Organisms & Idemili South and North & $(\mathrm{CFU} / 100 \mathrm{ml})$ & MEAN $\pm S T D$ & P-Value \\
\hline \multirow{2}{*}{ Salmonella typhi } & Surface water south & 40 & $1.275 \pm 0.452$ & \\
\hline & Surface water north & 85 & $8.831 \pm 1.673$ & $0.000^{*}$ \\
\hline \multirow{2}{*}{ Salmonella taratyphi $C$} & Surface water south & 10 & $5.000 \pm 0$ & \\
\hline & Surface water north & 139 & $19.244 \pm 1.6$ & $0.000^{*}$ \\
\hline \multirow{2}{*}{ Salmonella paratyphi A } & Surface water south & 35 & $3.428 \pm 0.502$ & \\
\hline & Surface water north & 114 & $14.373 \pm 1.79$ & $0.000^{*}$ \\
\hline \multirow{2}{*}{ Salmonella enterica } & Surface water south & 20 & $6.000 \pm 0$ & \\
\hline & Surface water north & 0 & $0.000 \pm 0$ & $0.000^{*}$ \\
\hline
\end{tabular}

P-Value is significant if $(p<0.05)$ and not significant if $(p>0.05)$

KEY:

* = Significant

$\mathrm{CFU}=$ Colony forming unit

$\mathrm{N}=$ Number of organism

$\mathrm{STD}=$ Standard Deviation

Table 7: Comparism of Salmonella spp found in surface water in Nnobi and Alor in Idemili south LGA of anambra state surface waters.

\begin{tabular}{|c|c|c|c|c|c|}
\hline Organism & Name of Community & (CFU/100ml) & MEAN \pm STD & P-Value & T-Value \\
\hline \multirow{2}{*}{ Salmonella typhi } & Nnobi & 0 & $0.000 \pm 0$ & & \\
\hline & Alor & 40 & $1.250 \pm 0.043$ & $0.000^{*}$ & - \\
\hline \multirow{2}{*}{ Salmonella paratyphi C } & Nnobi & 0 & $0.000 \pm 0$ & & - \\
\hline & Alor & 35 & $3.428 \pm 0.502$ & $0.000^{*}$ & \\
\hline \multirow{2}{*}{ Salmonella paratyphi A } & Nnobi & 30 & $5.333 \pm 0.479$ & & -10.897 \\
\hline & Alor & 10 & $7.000 \pm 0$ & $0.000^{*}$ & \\
\hline \multirow{2}{*}{ Salmonella enterica } & Nnobi & 10 & $7.000 \pm 0$ & $0.000^{*}$ & -19.039 \\
\hline & Alor & 20 & $8.000 \pm 0$ & & \\
\hline
\end{tabular}

P-Value is significant if $(p<0.05)$ and not significant if $(p>0.05)$

KEY:

* = Significant

$\mathrm{CFU}=$ Colony forming unit

$\mathrm{N}=$ Number of organism

STD $=$ Standard Deviation

Table 8: Comparism of Salmonella spp found in reservoirs in Nnobi and Alor in idemili south LGA of anambra state reservoirs

\begin{tabular}{|c|c|c|c|c|c|}
\hline Organism & Name of Community & CFU/100ml & MEAN \pm STD & T-Value & P-Value \\
\hline \multirow{2}{*}{ Salmonella typhi } & Nnobi & 19 & $1.000 \pm 0$ & 21.840 \\
\cline { 2 - 6 } & Alor & 150 & $2.000 \pm 0$ & $0.000^{*}$ \\
\hline \multirow{2}{*}{ Salmonella paratyphi C } & Nnobi & 0 & $0.000 \pm 0$ & $0.000^{*}$ \\
\hline \multirow{2}{*}{ Salmonella paratyphi A } & Alor & 19 & $7.000 \pm 0$ & \\
\cline { 2 - 6 } & Nnobi & 0 & $0.000 \pm 0$ & $0.000^{*}$ \\
\hline \multirow{2}{*}{ Salmonella enterica } & Alor & 0 & $5.137 \pm 0.775$ & 47.332 & \\
\cline { 2 - 6 } & Nnobi & 50 & $0.000 \pm 0$ & & $0.000^{*}$ \\
\hline
\end{tabular}

P-Value is significant if $(\mathrm{p}<0.05)$ and not significant if $(\mathrm{p}>0.05)$

KEY:

* = Significant

$\mathrm{CFU}=$ Colony forming unit

$\mathrm{N}=$ Number of organism

$\mathrm{STD}=$ Standard Deviation 
Table 9: Comparism of Salmonella spp found in bore holes in Abatete and Oraukwu in Idemili North LGA of anambra state bore hole

\begin{tabular}{|c|c|c|c|c|}
\hline Organism & Name of Community & (CFU/100ml) & MEAN $\pm S T D$ & P-Value \\
\hline \multirow{2}{*}{ Salmonella typhi } & Abatete & 0 & $0.000 \pm 0$ & \\
\hline & Oraukwu & 10 & $2.000 \pm 0$ & $0.000^{*}$ \\
\hline \multirow{2}{*}{ Salmonella paratyphi C } & Abatete & 10 & $0.909 \pm 0.301$ & $0.000 *$ \\
\hline & Oraukwu & 0 & $0.000 \pm 0$ & \\
\hline \multirow{2}{*}{ Salmonella paratyphi A } & Abatete & 0 & $0.000 \pm 0$ & \\
\hline & Oraukwu & 18 & $3.000 \pm 0$ & $0.000^{*}$ \\
\hline \multirow{2}{*}{ Salmonella enterica } & Abatete & 0 & $0.000 \pm 0$ & $0.000^{*}$ \\
\hline & Oraukwu & 40 & $0.000 \pm 0$ & \\
\hline
\end{tabular}

P-Value is significant if $(\mathrm{p}<0.05)$ and not significant if $(\mathrm{p}>0.05)$

KEY:

* =Significant

$\mathrm{CFU}=$ Colony forming unit

$\mathrm{N}=$ Number of organism

STD $=$ Standard Deviation

Table 10: Comparism of conventional and membrane methods used for isolation of Salmonalle spp. from waters bodies.

\begin{tabular}{|c|c|c|c|c|}
\hline Salmonella Spp. & Method of Isolation & Salmonalle Isolated & MEAN \pm STD & P-value \\
\hline \multirow{2}{*}{ Salmonella typhi } & Conventional method & 682 & $7.89 \pm 6.82$ & \\
\hline & Membrane Method & 124 & $3.18 \pm 1.14$ & $0.000^{*}$ \\
\hline \multirow{2}{*}{ Salmonella paratyphi A } & Conventional method & 263 & $19.45 \pm 2.01$ & \\
\hline & Membrane method & 158 & $7.79 \pm 1.24$ & $0.000^{*}$ \\
\hline \multirow{2}{*}{ Salmonella paratyphi $C$} & Conventional method & 95 & $25.00 \pm 1.17$ & \\
\hline & Membrane method & 7 & $7.00 \pm 0.00$ & $0.000^{*}$ \\
\hline \multirow{2}{*}{ Salmonella enterica } & Conventional method & 315 & $32.12 \pm 4.20$ & \\
\hline & Membrane method & 140 & $4.57 \pm 0.73$ & $0.000 *$ \\
\hline
\end{tabular}

P-Value is significant if $(\mathrm{p}<0.05)$ and not significant if $(\mathrm{p}>0.05)$

* Significant

Table 11: Condition of water sampled sources.

\begin{tabular}{|c|c|c|c|}
\hline Variable Sources of Water & Frequency & Prevalence (\%) & P -Value \\
\hline Borehole & 379 & 49.34 & $0.000 *$ \\
\hline Other sources & 101 & 64.35 & \\
\hline \multicolumn{4}{|c|}{ Storage mode of the borehole } \\
\hline Plastic overhead tank & 40 & 80 & $0.000^{*}$ \\
\hline Metal overhead tank & 10 & 20 & \\
\hline \multicolumn{4}{|c|}{ Regular washing of tanks } \\
\hline Yes & 32 & 68 & $0.000 *$ \\
\hline No & 48 & 90.5 & \\
\hline \multicolumn{4}{|c|}{ How often do you wash tank } \\
\hline Every 1-3 Weeks & 6 & 30 & $0.000 *$ \\
\hline 4-6 Weeks & 26 & & \\
\hline 6 Weeks and above & 48 & 92.5 & \\
\hline
\end{tabular}




\begin{tabular}{|c|c|c|c|}
\hline Less than 350ft & 35 & 83.5 & $0.224^{* *}$ \\
\hline Greater than 350ft & 14 & 87.3 & \\
\hline \multicolumn{5}{|c|}{ Sanitation observation within 10metres of pipeline } \\
\hline Yes & 21 & 75 & $0.002^{*}$ \\
\hline No & 59 & 81.9 & $0.000^{*}$ \\
\hline Yes & Defecation near the stream & \\
\hline No & 128 people & 59.21 & \\
\hline
\end{tabular}

Key: * - significant; ** - not significant.

NB: P-value $=<0.05$ significant, $>0.05$ not significant

Table 12: Chi square analysis showing effects of antibiotics to sensitivity resistance of some salmonella spp.

\begin{tabular}{|c|c|c|c|c|}
\hline \multicolumn{4}{|c|}{ Salmonella } & \multirow{2}{*}{ Total } \\
\hline Antibiotics & \multicolumn{2}{|c|}{ Sensitive } & Resistance & \\
\hline Streptomycin & Count & 17 & 0 & 17 \\
\hline Sensitive & Expected count & 3.8 & 13.2 & 12.0 \\
\hline Streptomycin & Count & 37 & 0 & 37 \\
\hline (Resist) & Expected count & 8.2 & 28.8 & 37.0 \\
\hline \multirow[t]{2}{*}{ Septrin(S) } & Count & 12 & 0 & 12 \\
\hline & Expected count & 2.7 & 9.3 & 12.0 \\
\hline \multirow{2}{*}{ Septrin(R) } & Count & 42 & 0 & 42 \\
\hline & Expected count & 9.3 & 32.1 & 42.0 \\
\hline \multirow{2}{*}{ Tarivid(S) } & Count & 0 & 19 & 19 \\
\hline & Expected count & 4.2 & 14.8 & 19.0 \\
\hline \multirow{2}{*}{ Tarivid(R) } & Count & 0 & 35 & 35 \\
\hline & Expected count & 7.8 & 27.2 & 35.0 \\
\hline \multirow{2}{*}{$\operatorname{Pef}(S)$} & Count & 0 & 6 & 6 \\
\hline & Expected count & 1.3 & 4.7 & 6.0 \\
\hline \multirow{2}{*}{$\operatorname{Pef}(\mathrm{R})$} & Count & 0 & 32 & 32 \\
\hline & Expected count & 7.1 & 24.9 & 32.0 \\
\hline \multirow{2}{*}{ Aug (S) } & Count & 0 & 22 & 22 \\
\hline & Expected count & 4.9 & 17.1 & 22.0 \\
\hline \multirow{2}{*}{ Aug (R) } & Count & 0 & 32 & 32 \\
\hline & Expected count & 7.1 & 24.9 & 32.0 \\
\hline \multirow{2}{*}{ Cipro (S) } & Count & 0 & 24 & 24 \\
\hline & Expected count & 5.3 & 18.7 & 24.0 \\
\hline \multirow{2}{*}{ Cipro (R) } & Count & 0 & 30 & 30 \\
\hline & Expected count & 6.7 & 23.3 & 30.0 \\
\hline \multirow{2}{*}{ Gent(S) } & Count & 0 & 10 & 10 \\
\hline & Expected count & 2.2 & 7.8 & 10.0 \\
\hline \multirow{2}{*}{ Gent(R) } & Count & 0 & 44 & 44 \\
\hline & Expected count & 9.8 & 34.2 & 44.0 \\
\hline \multirow{2}{*}{ Ampici (S) } & Count & 0 & 3 & 3 \\
\hline & Expected count & 7 & 2.3 & 3.0 \\
\hline \multirow{2}{*}{ Ampicillin (R) } & Count & 0 & 51 & 51 \\
\hline & Expected count & 11.3 & 39.7 & 51.0 \\
\hline \multirow{2}{*}{ Nalidic(S) } & Count & 0 & 9 & 9 \\
\hline & Expected count & 2.0 & 7.0 & 9.0 \\
\hline
\end{tabular}




\begin{tabular}{|c|c|c|c|c|}
\hline \multirow{2}{*}{ Nalidic(R) } & Count & 0 & 45 & 45 \\
\cline { 2 - 5 } & Expected count & 10.0 & 35.0 & 45.0 \\
\hline Total & Count & 108 & 378 & 486 \\
\hline & Expected count & 108.0 & 378.0 & 486.0 \\
\hline
\end{tabular}

$\mathrm{X} 2=486, \mathrm{DF}=17, \mathrm{P}=0.000(\mathrm{P}<0.5$, significant $)$

\section{Discussion}

The isolation of Salmonellaspp from water sample means that the direct consumption of such water without treatment May be very risky. The genus is known to cause Salmonellosis. The typhi and paratyphi species causes typhoid fever which can be spread through contaminated water.

This study, as expected shows that there is high bacteria load in the surface river water sample. These findings are in agreement with those reported by Doughari et al. [16] in Tiete River in Brazil and Adednego et al. [17] in Nairobi respectively. This study reveals that contamination of this surface water is by humans and other animal sources like bathing, farming and washing.

Surface waters from Oraukwu and Alor recorded high prevalence rate of Salmonella species. This is not surprising because some members of this community carryout a lot of farming activities near the surface water; some of them defecate along the farm land since their house is far from the farm, moreover, they all use bare hand to pack animal manures used for fertilizer on the farm land.

There is tendency that the surrounding flood from these farm lands may be carried into the stream. Also, this work also reveal that some of the spring waters from St. John Alor and Oraukwu (Nwaocha) recorded no bacteria growth at different spots collected. This may be attributed to the suggestion that spring water has natural filter that filters the water while a lot of indicator organism and Salmonella were recorded on the same source collected at different spots. This is attributed to the fact that contamination may be as a result of human activities like bathing, farming, washing etc.

From this present study, it shows that boreholes can also be contaminated through flood water which forms after rainfall, depending on the depth of the boreholes. Deeper boreholes contain little or no micro organisms since they are usually removed by extensive filtration as water percolates through the soil [18] as shown by the Nnobi borehole constructed by the government with depth $350 \mathrm{ft}$ when compared to borehole constructed by individuals in Alor, Oraukwu and Abatete who have little or no knowledge about importance and role of depth in sanitation of water.

Contamination could also be through broken underground pipes under this condition, the surrounding flood water flows into the pipe through the cracks [19]. Orji et al. [20] and several others have reported similar findings and recommended that household boreholes should be sited far away from soak-away pits and latrines.

In vitro disc susceptibility studies of the different isolates of Salmonella species obtained from the water sample showed that 9 drugs were susceptible isolates at different level. No isolate was sensitive to penicillin (30mg) $0(0 \%)$.Ciprofloxacin $(40 \mathrm{mg})$ was susceptible to $24(44.4 \%)$ of the isolated Salmonella species, it was the drug most sensitive to the different species of Salmonella.

The bacteriological analytical method recovered more of Salmonella species than membrane filtration method. In membrane filtration method, pressure from the filtration may have stressed the organisms, some of them are being lost but Bacteriological Analytical Method require only dilution method and the organisms are not stressed, this may contribute to high recovery rate of Salmonella species with the methodology. This also in similar with the work done by Umeh [21] on isolation of Salmonella species from powdered infant formular sold in Nnewi market.

\section{Conclusion}

The result of this study revealed that the water sources in these communities are highly polluted and is not safe for use by the communities for drinking or other domestic needs without prior treatment. There is need to monitor regularly and mitigate the effects of community behavior on surface waters. The results also indicate that some of these Salmonella spp. are resistant to some of the common antibiotics which if neglected becomes a very serious public health problem.

\section{References}

1. Ford TE (1999) Microbiological safety of drinking water. United States and global perspectives. Environmental Health Perspectives 107(1): 191-206.

2. Ezeugwunne IP, Agbakoba NR, Nnamah NK, Anhalu IC (2009) The prevalence of bacteria in packaged sachet water sold in Nnewi, south east, Nigeria. World Journal of Dairy and Food Science 4(1): 19-21.

3. Okonkoi IO, Ogunjobi AA, Adejoye AD, Ogunnusi TA, Olasogba MC (2008) Comparative studies and microbial risk assessment of different water samples used for processing frozen sea foods in Ijora-olopa, Lagos State, Nigeria. African Journal of Biotechnology 7(16): 2902-2907.

4. Umeh CN, Okorie OI, Emesinari GA (2005) Towards the provision of safe drinking water: The bacteriological quality and safety of sachet water in Awka, Anambra State. The book of abstract of the $29^{\text {th }}$ annual conference \& general meeting on microbes as agents of sustainable development organized by Nigeria Society for microbiology, Nigeria, pp. 22-23.

5. Oladipo IC, Onyenike IC, Adebiyi AO (2009) Microbiological analysis of some vended sachet water in Ogbomosho, Nigeira. African Journal of Food Science 3(12): 406-412.

6. Dufour A, Snozzi M, koster W, Bartram J, Ronchi E, et al. (2003) Assessing microbial safety of drinking water improving approaches and methods. Journal of Applied Microbiology 88: 1065-1165.

7. Ashblot NJ (2004) Microbial contamination of drinking water and disease outcomes in developing regions. Journal of Toxicology 198(1-3): 229-238.

8. Mengesha A, Mamo WB, Gelaw B (2004) A survey of bacteriological quality of drinking water in North Gonder. Ethiopian Journal of Health Development 18(2): 112-115. 
9. Clark TW, Daneshvar C, Pareek M, Perera N, Stephenson I (2010) Enteric fever in a Uk regional infections disease unit: Journal of Infections Disease 60(2): 91-98.

10. Ryan KJ, Ray CG (2004) Sherris Medical Microbiology ( $4^{\text {th }}$ edn), McGraw Hill, New York, pp. 294-295.

11. Ohalete CN, Dozie INS, Obiajuru IOC and Eke IH (2011) Studies on the ecology of salmonella bacili in Owerri Metropolis, Imo State, Nigeria. Global Research Journal of science 1: 109-116.

12. Cheesbrough M (2005) District Laboratory practices in tropical countries. United Kingdom Cambridge University Press, UK.

13. Environmental protection agency (2010) Standard analytical protocol for Salmonella typhi in drinking water. Washington DC, USA

14. Edwards PR, Ewing WH (1962) Identification of enterobacteriacae ( $2^{\text {nd }}$ edn), Burgers publishing Co., Minnesota, USA, pp. 203-205.

15. Wayne PA (2002) National committee for clinical and laboratory standard, Performance standard for antimicrobial disc susceptibility testing Approved standard M2-A5, Pennsylvania, USA, pp. 20-23.

16. Doughari J, Dodo J, Mbuh F (2007) Impact of affluent from gudu district sewage treatment plant on gudu stream in abuja, Nigeria. Journal of Applied Science and Environmental 11(1): 79-83.

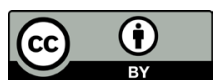

Creative Commons Attribution 4.0

International License

For possible submission use the below is the URL
17. Adednego MM, Baruk AS, John NM, Maingi JM (2013) Water bacteria pathogens in surface waters of Nairobi river and health implication to communities downstream Athi river. International Journal of Life Science \& Pharmaceutical research 3(1): 4-7.

18. Uzoigwe CI, Agwa KO (2012) Microbiological quality of water collected from boreholes sited near refuse dumpsites in Port Harcourt, Nigeria. African Journal of Biotechnology 11(13): 3135-3139.

19. Nwachukwu CI, Otokunefor TV (2006) Bacteriological quality of drinking water supplies in the university of Port Harcourt, Nigeria. Nigeria Journal of Microbiology 20(3): 1383-1388.

20. Orji MU, Ezenwaje EE, Anyaegbunam BC (2006) Spatial appraisal of shallow well water pollution in Awka, Nigeria. Nigeria Journal of Microbiology 20(3): 1389-1394.

21. Umeh AC (2014) Isolation of Salmonella species from powdered infant formula sold in Nnewi market, Unpublished post graduate diploma thesis. Department of Medical Laboratory Science, Nnamdi Azikiwe University Awka, Nigeria.

\section{Your subsequent submission with Crimson Publishers will attain the below benefits}

- High-level peer review and editorial services

- Freely accessible online immediately upon publication

- Authors retain the copyright to their work

- Licensing it under a Creative Commons license

- Visibility through different online platforms

- Global attainment for your research

- Article availability in different formats (Pdf, E-pub, Full Text)

- Endless customer service

- Reasonable Membership services

- Reprints availability upon request

- One step article tracking system 